\title{
SCOPE model applied for rapeseed in Spain
}

\author{
Nuria Pardo ${ }^{\text {a,* }}$, M. Luisa Sánchez ${ }^{\text {a }}$, Zhongbo Su ${ }^{\text {b }}$, Isidro A. Pérez ${ }^{\text {a }}$, M. Angeles García ${ }^{\text {a }}$ \\ a Department of Applied Physics, University of Valladolid, Valladolid, Spain \\ b Department of Water Resources, Faculty of Geo-Information Science and Earth Observation (ITC), University of Twente, Enschede, The Netherlands
}

\section{H I G H L I G H T S}

- SCOPE uses a two-source model to calculate energy fluxes and $\mathrm{CO}_{2}$ exchanges.

- The integrated model SCOPE revealed great results in simulating $\mathrm{CO}_{2}$ fluxes.

- Characteristic photosynthetic parameters $\left(\mathrm{V}_{\mathrm{cmax}}, \mathrm{J}_{\max }\right)$ for rapeseed were obtained.

- A sink behaviour for rapeseed was also found when simulating NEE with SCOPE.

\author{
G R A P H I C A L A B S T R A C T
}

Linear relationship for NEE between observed and SCOPE-modelled
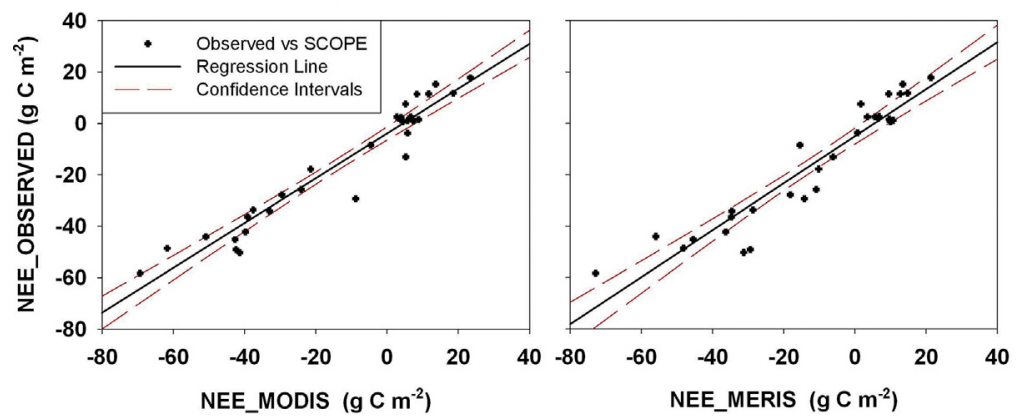

\section{A B S T R A C T}

The integrated SCOPE (Soil, Canopy Observation, Photochemistry and Energy balance) model, coupling radiative transfer theory and biochemistry, was applied to a biodiesel crop grown in a Spanish agricultural area. Energy fluxes and $\mathrm{CO}_{2}$ exchange were simulated with this model for the period spanning January 2008 to October 2008. Results were compared to experimental measurements performed using eddy covariance and meteorological instrumentation. The reliability of the model was proven by simulating latent (LE) and sensible ( $\mathrm{H})$ heat fluxes, soil heat flux $(\mathrm{G})$, and $\mathrm{CO}_{2}$ exchanges (NEE and GPP). LAI data used as input in the model were retrieved from the MODIS and MERIS sensors. SCOPE was able to reproduce similar seasonal trends to those measured for NEE, GPP and LE. When considering $\mathrm{H}$, the modelled values were underestimated for the period covering July 2008 to mid-September 2008. The modelled fluxes reproduced the observed seasonal evolution with determination coefficients of over 0.77 when $\mathrm{LE}$ and $\mathrm{H}$ were evaluated. The modelled results offered good agreement with observed data for NEE and GPP, regardless of whether LAI data belonged to MODIS or MERIS, showing slopes of 0.87 and 0.91 for NEE-MODIS and NEE-MERIS, and 0.91 and 0.94 for GPP-MODIS and GPP-MERIS, respectively. Moreover, SCOPE was able to reproduce similar seasonal behaviours to those observed for the experimental carbon fluxes, clearly showing the $\mathrm{CO}_{2} \operatorname{sink} /$ source behaviour for the whole period studied.

(c) 2018 Elsevier B.V. All rights reserved.

\footnotetext{
* Corresponding author.

E-mail address: npardo@fa1.uva.es (N. Pardo).
}

\section{Introduction}

The dynamics of the various ecosystems has been widely studied. Knowledge of this dynamic behaviour can help to quantify the role played by the different types of ecosystem in the global carbon, energy, and hydrological cycles. The enormous relevance in different scientific applications of the various biophysical processes at land surface level, 
or relating atmosphere and surface/ecosystem, has thus led to the development of models able to reproduce a wide range of such processes, in particular those related to energy, carbon, and water exchange.

Radiative transfer models based on the radiative transfer theory were developed as a tool to describe canopy behaviour with regard to its interaction with radiation (Liang et al., 2012; Clough et al., 2005; Kötz et al., 2004; Dorigo et al., 2007). The most well-known and widely studied radiative transfer models are probably those used in SCOPE (Soil, Canopy Observation, Photochemistry and Energy fluxes): SAIL (Verhoef, 1984; Verhoef et al., 2007) and PROSPECT (Jacquemoud and Baret, 1990; Jacquemoud et al., 2009).

Energy balance models are commonly divided into one or twosource models (Gonzalez-Dugo et al., 2009; Kustas et al., 1996; Kalma et al., 2008; Li et al., 2009; Song et al., 2016; Tang et al., 2013). A formulation developed for two-source models was described by Shuttleworth and Wallace (1985). The model assimilated the ecosystem as a system defined through two resistances. Since then, several approaches to this formulation have been widely studied and applied (Norman et al., 1995). As described in Wallace and Verhoef (2000), when several sources are taken into consideration when developing SVAT (Soil-Vegetation-Atmosphere Transfer) models, various resistances should be calculated to fully describe the system, as is the method applied in SCOPE, differentiating between soil and canopy. If interaction between the various fluxes is considered, all the different components considered in this approach have different aerodynamic and surface resistances characterizing their influence.

The simplest biochemical model uses a single layer approach (known as the big-leaf model), although new models using two-leaf or multilayer approaches have also been widely studied (Kremer et al., 2008). Chen et al. (1999) present Farquhar's model (Farquhar et al., 1980) as one of the most successful in modeling canopy photosynthesis and summarize the different approaches used to enhance the original model. In two-leaf model calculations, the canopy is divided into sunlit and shaded leaves (Xin et al., 2015). The various fluxes and photosynthesis rates are thus estimated separately for each leaf type. One such approach, the one used in this study, applies the separation into sunlit and shaded leaves (Wang and Leuning, 1998) when simulating energy and $\mathrm{CO}_{2}$ fluxes.

The 1-D SCOPE model was proposed (Van der Tol et al., 2009) as an integrated radiative transfer, photochemistry, and energy balance multilayer model. The main purpose of this model is to estimate the most important biophysical processes involved in an ecosystem. The SCOPE model based on Farquhar's model could thus be used to evaluate the response of various crops to changes in $\mathrm{CO}_{2}$ concentration, which is known to be increasing (IPCC, 2013). Previous studies evaluating SCOPE have mainly focused on sun-induced (chlorophyll) fluorescence (Thum et al., 2017; Du et al., 2017; Verrelst et al., 2015) rather than on carbon fluxes. When carbon fluxes have been evaluated, they have been applied to crops or types of vegetation (Liu et al., 2017) different to the one studied in this paper. Rapeseed (Brassica napus L.) is a crop that has gained importance by considerably increasing both its harvested area and production over the last twenty years (FAOSTAT, http://www.fao.org/faostat/). This increase has been particularly noticeable in Spain since 2001 (MAGRAMA, http://www.mapama.gob.es/ es/estadistica/temas/publicaciones/anuario-de-estadistica/). Moreover, rapeseed is a crop which has scarcely been analysed thus far, thereby increasing the interest of the present study. This study therefore aims to evaluate the reliability of SCOPE regarding energy fluxes and carbon exchange on an agricultural ecosystem where rapeseed was grown. The objectives of this paper are:

1) to obtain carbon and energy fluxes by applying the SCOPE model,

2) to compare them against experimental measurements in order to calibrate the model for the ecosystem evaluated in this paper, and

3) to retrieve the characteristic parameters describing the various processes by calibrating the model.

\section{Study area and instrumentation}

\subsection{Study area}

The study area ( $41^{\circ} 46^{\prime} 44.4^{\prime \prime} \mathrm{N}, 4^{\circ} 52^{\prime} 19.19^{\prime \prime} \mathrm{W}, 849 \mathrm{~m}$ a.m.s.l.) is located on the central Spanish plateau. The farmland where measurements were performed is located in a semi-arid area, some $30 \mathrm{~km}$ north west of Valladolid (Fig. 1) in Castilla y León (Spain). The climate characterizing this region is Mediterranean-Continental with low temperatures in winter months, and warm and dry summers. Air temperature usually peaks in July or August with values around $36{ }^{\circ} \mathrm{C}$, whereas minimum values are found in January or December, and may drop to as low as $-10{ }^{\circ} \mathrm{C}$. Precipitation is seasonally distributed with an average sum of $450 \mathrm{~mm}$ for a 35-year period. Precipitation events occur mainly in spring (April to June) and again in October, November, or December depending on the year. The yearly accumulated precipitation for the full year of 2008 reached $497 \mathrm{~mm}$. The maximum crop growth (hereafter referred to as MIP -Maximum Interest Period-) was considered from March to June in this study, with accumulated precipitation of 237 $\mathrm{mm}$ for this period. Two clearly differentiated periods can be considered in the study area, namely a wet period and a dry period. The dry period was determined by the last precipitation event, after the harvest, followed by at least 15 days without precipitation. This period covered 24 June 2008 to 6 October 2008. Accumulated precipitation for this period was $34 \mathrm{~mm}$, and the average air temperature was $17^{\circ} \mathrm{C}$. The remainder of the yearly period was defined as a wet period.

The farmland where measurements were performed is divided into single plots where a rotation scheme is carried out under reduced tillage management. One of those single plots, covering an area of about 36 ha, was the place chosen to carry out the measurements (Fig. 1). The large size and horizontal homogeneity of the terrain, coupled with the fact that the main wind direction (WSW-NE) concurs with the orientation of the study plot, yielded eddy covariance (EC) measurements representing the whole study plot (Burba and Anderson, 2010; Leclerc and Foken, 2014).

The rotation cycle in the single plot usually includes several of the most representative non-irrigated crops in the region such as: rapeseed, wheat/barley, peas, rye, and sunflower. The typical growth period for these crops usually covers from seedtime to mid-July the following year when the crop is harvested. The rest of the time, soil only presents residue coverage, characteristic of reduced tillage practices. The rapeseed studied in this paper was seeded in mid-September 2007 and harvested in mid-July 2008. Soil composition is sandy loam with a content of between $60 \%$ to $65 \%$ sand, $20 \%$ clay, and about $15 \%$ silt.

\subsection{Instrumentation}

Measurements have been conducted continuously since March 2008 in the sampling plot. The validation period considered in this study covered from March 2008 to October 2008. Two towers were installed to perform these measurements. The first tower incorporates the EC system which uses a 3D sonic anemometer (USA-1, METEK, Germany) measuring wind speed and direction, and an open path infrared gas analyzer -IRGA- measuring carbon and water densities/concentrations $3.5 \mathrm{~m}$ above the surface (Li-7500, Li-Cor Inc., Lincoln, NE, USA). This instrumentation records instantaneous data with a $10 \mathrm{~Hz}$ sampling frequency. A tower located a few metres from this first tower is equipped with the meteorological instrumentation. Wind speed and direction (Wind sentry Model 03002, Young, Campbell Scientific, Inc.), air temperature and humidity (model STH-5031, Geónica, Spain), net radiation (net radiometer type 8110 , Ph. Schenk), and soil temperature and moisture (model STS-5031, Geónica, Spain; model 6545, Type ML2x, ThetaProbe) are measured. A quantum sensor (LI-190Sz, Li-Cor Inc., Lincoln, NE, USA) is also located in this tower to measure PAR (Photosynthetically Active Radiation). The soil heat flux is averaged from two soil heat flux plates (HFP01, HukseFlux, Delft, The Netherlands), one 


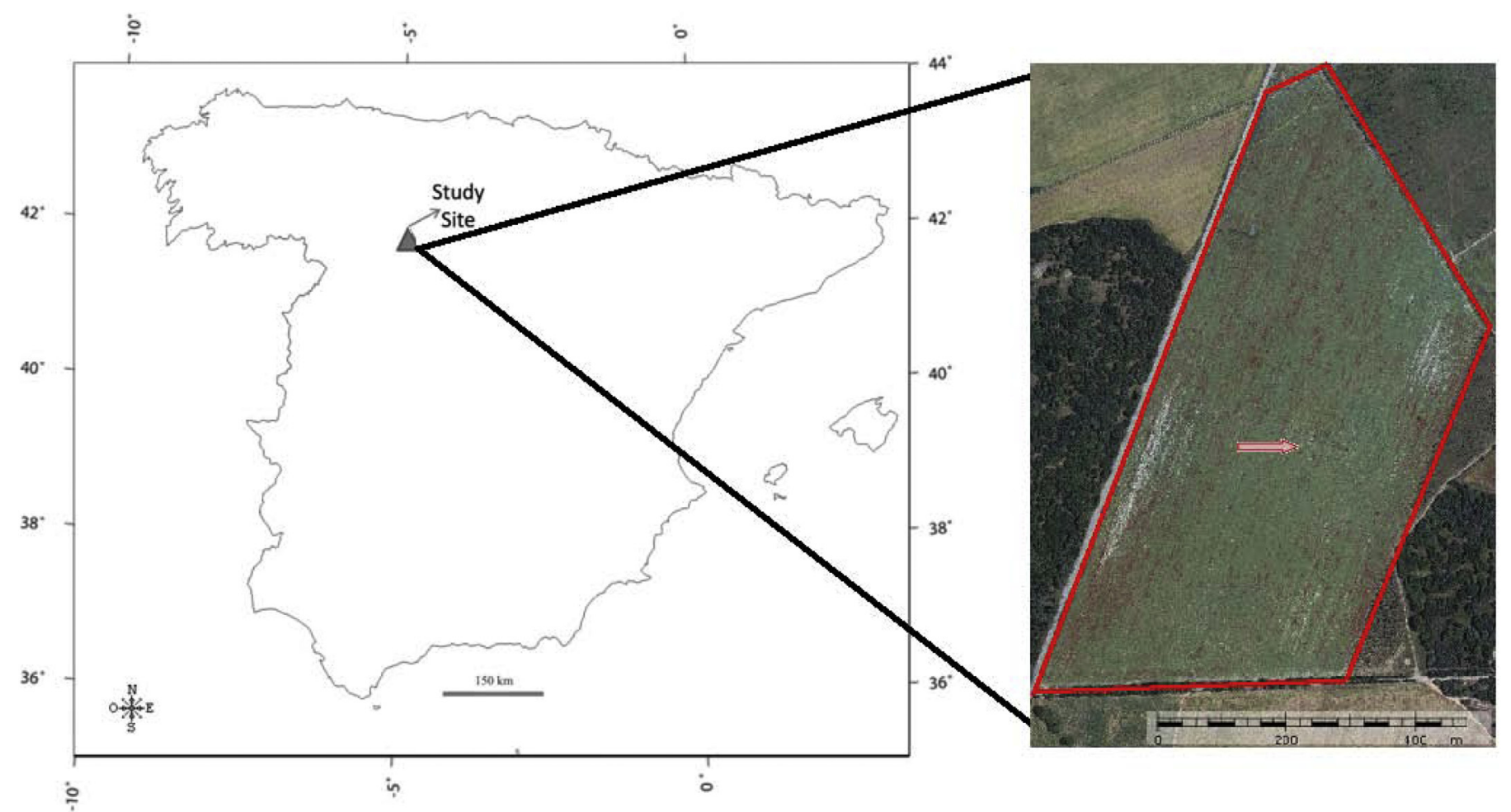

Fig. 1. Location and boundaries of the area studied. The arrow indicates the location of the instrumentation. PNOA image (right) courtesy of $\subset$ ign.es.

under vegetation and the other under bare soil, which are buried about $5 \mathrm{~cm}$ below surface in the proximity of the tower.

As ancillary data, Leaf Area Index (LAI) was measured during the MIP with a LAI-2000 (Li-Cor Inc.). As mentioned earlier, the MIP was defined between March and June for this research. LAI data from MERIS and MODIS sensors were thus retrieved as a means of obtaining a full yearly dataset to be used as input in SCOPE, since experimental LAI measurements were constrained to said MIP.

\section{Methodology}

\subsection{Experimental procedure}

The EC system returns NEE (Net Ecosystem Exchange) values measured directly with the instrumentation. The relationship between these values and instantaneous GPP (Gross Primary Production) is given by the difference between NEE and total ecosystem respiration $\left(\mathrm{R}_{\text {eco }}\right)$, as defined by

$\mathrm{GPP}=-\mathrm{NEE}+\mathrm{R}_{\text {eco }}$

The TK2 software package developed by Bayreuth University (Mauder and Foken, 2004) was used to process raw data. Different corrections were applied inside the software such as despiking, time lag and frequency response correction, coordinate correction, and WPL (Webb-Pearman-Leuning) correction (Mauder and Foken, 2004). Daytime NEE values were gap-filled by applying a non-linear regression given by Michaelis-Menten equation (Yang et al., 2011; Falge et al., 2001).

Since vegetation does not undergo photosynthesis during the nighttime due to the lack of light, NEE values measured during this period might be equated to $R_{\text {eco. }}$. This respiration could therefore be parameterized from observed night-time values measured with the EC system (Wang et al., 2012; Sierra et al., 2011). A modified Van't Hoff equation dependent on air temperature (Ta) and soil moisture (SM) was applied to these observed night-time NEE in order to obtain parameterized respiration (Sánchez et al., 2015):

$\mathrm{R}_{\text {eco }}=\operatorname{parm} 1 * \mathrm{SM} * \exp (\operatorname{parm} 2 * \mathrm{Ta})$

The unknown parameters, parm 1 and parm2, were estimated using the Marquardt algorithm from Statgraphics Centurion. Eq. (2) was applied to the period covering March to October. Once a parameterized equation for respiration had been obtained it was applied during the daytime to compute $R_{\text {eco, }}$ and, finally, instantaneous GPP values were calculated by applying Eq. (1).

As stated previously, ground-based LAI data were measured during the MIP. LAI reflects crop development perfectly, and is therefore one of the most influential inputs in SCOPE for obtaining carbon fluxes (see Section 4). A full yearly dataset is desirable and, in this regard, remote sensing is a useful tool. MODIS and MERIS sensors provide LAI measurements on a yearly basis although, as reported in the literature (Tang et al., 2011), these measurements tend to underestimate compared to experimental ones. In order to obtain a more realistic and yearly LAI database, MERIS remote sensing values were therefore calibrated using ground-based data through a linear relationship between them. Finally, the values for LAI (based on remote sensing data) were used in SCOPE.

\subsection{Model overview/methodology}

The SCOPE model structure comprises several modules (Fig. 2). First, modules related to radiative transfer theory, using the PROSPECT and SAIL models, are executed to predict optical properties and the top of the canopy radiance spectrum as well as the distribution of the PAR and net radiation $\left(R_{n}\right)$. The Farquhar photochemistry model is then applied combined with a two-source energy balance model calculating carbon assimilation/photosynthesis and turbulent fluxes and soil heat flux, respectively. 


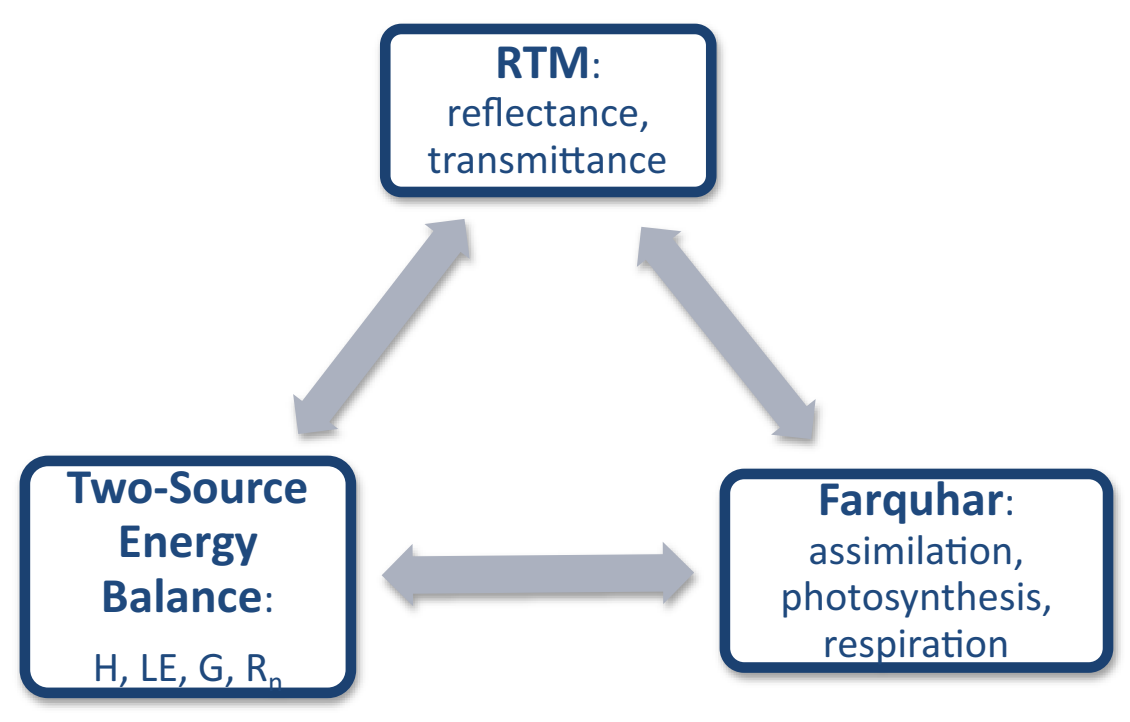

Fig. 2. Main modules involved in the SCOPE model.

The radiative transfer theory employed in SCOPE is based on Verhoef (1984). SCOPE first simulates optical properties of the leaves by applying PROSPECT. These products are then applied in the SAIL model to obtain the canopy reflectance and radiation used as input in the energy balance module.

One feature of the radiative transfer models is to divide the canopy into elementary layers. The optical properties simulated by radiative transfer models are governed not only by surface properties but by the shape and internal structure of the leaves. Canopy geometry and features are described by defining several parameters. These radiative transfer parameters in SCOPE are: chlorophyll content $\left(\mathrm{C}_{\mathrm{ab}}\right)$, dry material concentration $\left(C_{d m}\right)$, water concentration $\left(C_{w}\right)$, senescent material concentration $\left(\mathrm{C}_{\mathrm{S}}\right)$, thickness parameter $(\mathrm{N})$, and the leaf angle distribution function (LADF) which characterizes the leaf type (spherical, planophile, erectophile). Values for all of these input parameters (see Table 1) were fixed taking into account suitable ranges given in the

Table 1

Main input parameters for SCOPE. A more detailed description of the input parameters/ variables can be found in: Verrelst et al. (2015) and Van der Tol et al. (2009).

\begin{tabular}{|c|c|c|c|}
\hline Parameter & Symbol & Units & Comments \\
\hline Chlorophyll content & $\mathrm{C}_{\mathrm{ab}}$ & $\begin{array}{l}\mu \mathrm{g} \\
\mathrm{cm}^{-2}\end{array}$ & 70 \\
\hline $\begin{array}{l}\text { Dry material } \\
\text { concentration }\end{array}$ & $C_{d m}$ & $\mathrm{~g} \mathrm{~cm}^{-2}$ & 0.005 \\
\hline Water concentration & $\mathrm{C}_{\mathrm{w}}$ & $\mathrm{cm}$ & 0.011 \\
\hline $\begin{array}{l}\text { Senescent material } \\
\text { concentration }\end{array}$ & $\mathrm{C}_{\mathrm{s}}$ & Unitless & 0 \\
\hline Thickness parameter & $\mathrm{N}$ & Unitless & 1.8 \\
\hline $\begin{array}{l}\text { Leaf angle distribution } \\
\text { function }\end{array}$ & LADF & Unitless & $\begin{array}{l}\text { Verrelst et al. (2015) } \\
\text { Van der Tol et al. (2009) }\end{array}$ \\
\hline Leaf area index & LAI & $\begin{array}{l}\mathrm{m}^{2} \\
\mathrm{~m}^{-2}\end{array}$ & $\begin{array}{l}\text { Field measurement/Remote } \\
\text { Sensing observations }\end{array}$ \\
\hline Incoming radiation & & $\mathrm{W} \mathrm{m} \mathrm{m}^{-2}$ & From meteorological observations \\
\hline Canopy height & $\mathrm{h}$ & $\mathrm{m}$ & Field measurement \\
\hline Soil moisture & SM & $\%$ & Field measurement \\
\hline Air temperature & $\mathrm{Ta}$ & ${ }^{\circ} \mathrm{C}$ & Field measurement \\
\hline Wind speed & $\mathrm{u}$ & $\mathrm{m} \mathrm{s}^{-1}$ & Field measurement \\
\hline $\begin{array}{l}\text { Atmospheric } \mathrm{CO}_{2} \\
\text { concentration }\end{array}$ & $\mathrm{Ca}$ & ppm & 380 \\
\hline $\begin{array}{r}\text { Atmospheric } \mathrm{O}_{2} \\
\text { concentration }\end{array}$ & Oa & ppm & 220 \\
\hline $\begin{array}{l}\text { Meteorological } \\
\text { measurement height }\end{array}$ & $\mathrm{z}$ & $\mathrm{m}$ & 2.5 \\
\hline Pressure & $\mathrm{p}$ & mbar & {$[910,925]$} \\
\hline
\end{tabular}

literature for similar vegetation and locations (Atzberger and Richter, 2012; González-Sanpedro et al., 2008).

In this paper, we focus on calibrating the biochemical and energy balance modules. Therefore, the formulation related to radiative transfer models based modules is not described. For a more detailed description of this methodology and for further information see Van der Tol et al. (2009) and Verhoef (1984).

Biochemical processes are studied here by applying Farquhar's model (Farquhar et al., 1980). This model was specifically developed to assess photosynthetic carbon assimilation regarding C3 plants. Since a C3 plant is studied in this research, only this biochemical model was applied. However, SCOPE has been developed to work with both $\mathrm{C} 3$ and $\mathrm{C} 4$ types.

Farquhar's model calculates photosynthesis considering two different cases (Farquhar et al., 1980; Groenendijk et al., 2011a) depending on whether the photosynthesis rate is limited/constrained by Rubisco or light/electron transport. Farquhar defined these cases by $\mathrm{W}_{\mathrm{c}}$ and $\mathrm{W}_{\mathrm{j}}$, respectively.

$\mathrm{W}_{\mathrm{c}}=\mathrm{V}_{\mathrm{cmax}} \frac{\mathrm{C}_{\mathrm{i}}}{\mathrm{k}_{\mathrm{c}}\left(1+\frac{\mathrm{O}}{\mathrm{k}_{\mathrm{O}}}\right)+\mathrm{C}_{\mathrm{i}}}$

$\mathrm{W}_{\mathrm{j}}=\frac{\mathrm{J}}{4} \frac{\mathrm{C}_{\mathrm{i}}}{\mathrm{C}_{\mathrm{i}}+2 \cdot \Gamma_{*}}$

$\Gamma_{*}=0.5 \frac{\mathrm{V}_{\mathrm{Omax}}}{\mathrm{V}_{\mathrm{cmax}}} \frac{\mathrm{k}_{\mathrm{c}}}{\mathrm{Ok}_{\mathrm{O}}}$

where $\mathrm{C}_{\mathrm{i}}$ is the internal leaf $\mathrm{CO}_{2}$ concentration $\left(\mu \mathrm{mol} \mathrm{m}{ }^{-3}\right), \mathrm{O}$ is the partial pressure of $\mathrm{O}_{2}\left(\mathrm{mmol} \mathrm{m}^{-3}\right), \mathrm{k}_{\mathrm{c}}(\mu \mathrm{bar})$ and $\mathrm{k}_{\mathrm{o}}$ (mbar) are the Michaelis-Menten constants for $\mathrm{CO}_{2}$ and $\mathrm{O}_{2}$, respectively, and $\mathrm{V}_{\mathrm{cmax}}$ and $\mathrm{V}_{0 \max }\left(\mu \mathrm{mol} \mathrm{m} \mathrm{m}^{-2} \mathrm{~s}^{-1}\right.$ ) are the maximum carboxylase and oxygenase velocities, respectively. $\Gamma_{*}$ is known as the compensation point and is calculated following the formulation given by Farquhar (Farquhar et al., 1980; Bernacchi et al., 2001; Dai et al., 2004) as described in Eq. (5).

The potential rate of electron transport $(\mathrm{J})$ is defined as follows

$\mathrm{J}=\frac{0.82 \cdot \mathrm{J}_{\max } \cdot \mathrm{PAR}}{2 \cdot \mathrm{J}_{\max }+0.82 \cdot \mathrm{PAR}}$

with $\mathrm{J}_{\max }$ being the maximum electron transport rate in units of $\mu \mathrm{mol}$ $\mathrm{m}^{-2} \mathrm{~s}^{-1}$. PAR is also in the same units. 
Gross photosynthesis or gross assimilation (A, also denoted as GPP) was thus calculated following Farquhar's model (Von Caemmerer, 2000; Lenz et al., 2010) as a combination of the previously calculated photosynthesis rates.

The next step in the model is to calculate all of the energy balance components. Aerodynamic resistances, used in the energy balance module, were calculated following the description in Wallace and Verhoef (2000), which characterizes the system by the three most widely used resistances. Loss of water from vegetation is regulated by stomata. This stomatal aperture can be expressed as a stomatal resistance governing water flow from vegetation to the atmosphere. Therefore, a stomatal resistance $\left(\mathrm{r}_{\text {stom }}^{\mathrm{c}}\right.$ ) is also calculated in this module. This resistance is used in the calculation of turbulent fluxes (see below).

The total aerodynamic resistance above the canopy might be partitioned as follows,

$\mathrm{r}_{\mathrm{a}}^{\mathrm{a}}=\mathrm{r}_{\mathrm{a}}^{\mathrm{c}}+\mathrm{r}_{\mathrm{a}}^{\mathrm{i}}+\mathrm{r}_{\mathrm{a}}^{\mathrm{r}}$

where $\mathrm{r}_{\mathrm{a}}^{\mathrm{c}}, \mathrm{r}_{\mathrm{a}}^{\mathrm{i}}, \mathrm{r}_{\mathrm{a}}^{\mathrm{r}}$ are the aerodynamic resistance in the canopy layer, in the inertial sublayer and in the roughness sublayer, respectively. These resistances are described by,

$r_{a}^{c}=\frac{h \cdot \sinh (n)}{n \cdot K(h)}\left[\ln \left(\frac{e^{n}-1}{e^{n}+1}\right)-\ln \left(\frac{e^{n[20 m+d]} / h-1}{e^{n[20 m+d]} / h+1}\right)\right]$

$\mathrm{r}_{\mathrm{a}}^{\mathrm{i}}=\frac{1}{\mathrm{k} \cdot \mathrm{u}_{\mathrm{star}}}\left[\ln \frac{\mathrm{z}-\mathrm{d}}{\mathrm{z}_{\mathrm{R}}-\mathrm{d}}-\Psi_{\mathrm{h}}(\mathrm{z})+\Psi_{\mathrm{h}}\left(\mathrm{z}_{\mathrm{R}}\right)\right]$

$\mathrm{r}_{\mathrm{a}}^{\mathrm{r}}=\frac{1}{\mathrm{k} \cdot \mathrm{u}_{\mathrm{star}}} \frac{\mathrm{z}_{\mathrm{R}}-\mathrm{h}}{\mathrm{z}_{\mathrm{R}}-\mathrm{d}}-\Psi_{\mathrm{h}}^{*}\left(\mathrm{z}_{\mathrm{R}}\right)+\Psi_{\mathrm{h}}^{*}(\mathrm{~h})$

where $\mathrm{k}$ is von Karman's constant, $\mathrm{K}$ is the eddy diffusivity, $\mathrm{u}_{\text {star }}$ is the friction velocity, $\mathrm{h}$ is the height of the canopy, and $\mathrm{d}$ is the zero-plane displacement. Stability correction functions are given by $\Psi_{\mathrm{h}}$ and $\Psi_{\mathrm{h}}^{*}$ (Wallace and Verhoef, 2000). Different heights are also considered in the above equations: $z$ is the reference height, $z_{R}$ is the height of the roughness sublayer, and $\mathrm{z}_{0 \mathrm{~m}}$ is the roughness height for momentum. The wind extinction coefficient in Eq. (8) is calculated as follows,

$\mathrm{n}=\frac{\mathrm{C}_{\mathrm{d}} \cdot \mathrm{LAI}}{2 \cdot \mathrm{k}^{2}}$

where $C_{d}$ is a drag coefficient with a constant value of 0.2 .

Similarly, the total aerodynamic resistance within the canopy $\left(\mathrm{r}_{\mathrm{aw}}\right)$ is influenced by the canopy itself and by the soil. Two components could thus be considered for this resistance, one regarding canopy influence,

$\mathrm{r}_{\mathrm{aw}}{ }^{\mathrm{c}}=\mathbf{r}_{\mathrm{w}}{ }^{\mathrm{c}}+\mathrm{r}_{\mathrm{b}}{ }^{\mathrm{c}}$

and the other related to soil influence,

$\mathrm{r}_{\mathrm{aw}}{ }^{\mathrm{s}}=\mathrm{r}_{\mathrm{w}}{ }^{\mathrm{s}}+\mathbf{r}_{\mathbf{b}} \mathrm{s}$

where $\mathrm{r}_{\mathrm{b}}^{\mathrm{c} / \mathrm{s}}$ is the boundary layer resistance, and $\mathrm{r}_{\mathrm{w}}^{\mathrm{c} / \mathrm{s}}$ is the aerodynamic resistance within the canopy. Superscripts $c$ and $s$ therefore refer to canopy and soil, respectively. Boundary layer resistance $\left(\mathrm{r}_{\mathrm{b}}^{\mathrm{c}}\right)$ and aerodynamic resistance $r_{\mathrm{w}}^{\mathrm{s}}$ are calculated as indicated by Van der Tol et al. (2009) and Wallace and Verhoef (2000). The remaining resistances in Eqs. (12)-(13), $\mathbf{r}_{\mathbf{w}}^{\mathbf{c}}$ and $\mathbf{r}_{\mathbf{b}}^{\mathbf{s}}$, are fixed values for the study period. The value of $\mathbf{r}_{\mathbf{w}}^{\mathbf{c}}$ depends on the study period: $50 \mathrm{~s} \mathrm{~m}^{-1}$ for the wet period and $0 \mathrm{~s} \mathrm{~m}^{-1}$ for the dry period; while a fixed value of $10 \mathrm{~s} \mathrm{~m}^{-1}$ is used for $\mathbf{r}_{\mathbf{b}}^{\mathbf{s}}$. Soil surface resistance $\left(\mathbf{r}_{\mathbf{s}}^{\mathbf{s}}\right)$ which characterizes soil features, is also considered a fixed value for a chosen study period $\left(2500 \mathrm{~s} \mathrm{~m}^{-1}\right.$ for the dry period, and $250 \mathrm{~s} \mathrm{~m}^{-1}$ for the wet period). Following the indications given by Frield (2002), the resistance values used to run SCOPE have been characteristic for each period regarding crop
Table 2

Definition of the resistances used in SCOPE. All resistances are in units of $\mathrm{s} \mathrm{m}^{-1}$

\begin{tabular}{lll}
\hline & Canopy & Soil \\
\hline $\mathbf{r}_{\mathbf{H}}$ & $\mathrm{r}_{\mathrm{a}}^{\mathrm{a}}+\mathrm{r}_{\mathrm{aw}}^{\mathrm{c}}$ & $\mathrm{r}_{\mathrm{a}}^{\mathrm{a}}+\mathrm{r}_{\mathrm{aw}}^{\mathrm{s}}$ \\
$\mathbf{r}_{\mathbf{L E}}$ & $\mathrm{r}_{\mathrm{a}}^{\mathrm{a}}+\mathrm{r}_{\mathrm{aw}}^{\mathrm{c}}+\mathrm{r}_{\mathrm{stom}}^{\mathrm{c}}$ & $\mathrm{r}_{\mathrm{a}}^{\mathrm{a}}+\mathrm{r}_{\mathrm{aw}}^{\mathrm{s}}+\mathrm{r}_{\mathrm{s}}^{\mathrm{s}}$ \\
\hline
\end{tabular}

development and moisture conditions. The resistances defined above are involved in the calculation of the turbulent fluxes in units of $\mathrm{W}$ $\mathrm{m}^{-2}$ (Timmermans et al., 2007; Xin and Liu, 2010) as follows,

$\mathrm{H}=\rho c_{\mathrm{p}} \frac{\mathrm{T}_{2}-\mathrm{T}_{1}}{\mathrm{r}_{\mathrm{H}}}$

$\mathrm{LE}=\lambda \frac{\mathrm{q}_{2}-\mathrm{q}_{1}}{\mathrm{r}_{\mathrm{LE}}}$

where $r_{H}$ and $r_{L E}$ are total resistances, defined in Table 2, for each element taken into consideration in the analysis.

Finally, $\mathrm{G}$ is calculated by a relationship with the net radiation widely used in the literature (Morillas et al., 2013; Choudhury et al., 1987) as follows

$\mathrm{G}=0.27 \cdot \mathrm{R}_{\mathrm{n}} \exp (-0.32 \cdot \mathrm{LAI})$

The characteristic parameters employed in Eq. (16) were calculated in a previous study for the same ecosystem (Pardo et al., 2014). The energy balance closure for the study site was previously quantified in Pardo et al. (2015), but in the evaluation made for the SCOPE model the energy fluxes were not corrected for the imbalance. Therefore, heat storage for soil heat flux was not taken into consideration.

\section{Results}

\subsection{LAI input data}

As stated in Section 3, two series of LAI data from remote sensing were used separately in SCOPE, MODIS (collection v6) and MERIS data. These data were compared to experimental LAI measurements. Since experimental LAI was only measured during the MIP, the comparison with remote sensing data was confined to those values. The results from this comparison showed that LAI retrieved from remote sensing was underestimated with slopes of 1.10 and 1.18 for MODIS and MERIS, and with the determination coefficient $\left(R^{2}\right)$ reaching values of 72.9 and $86.6 \%$ for MODIS and MERIS, respectively. The results displayed in Fig. 3 show that MODIS LAI data reached almost the same maximum

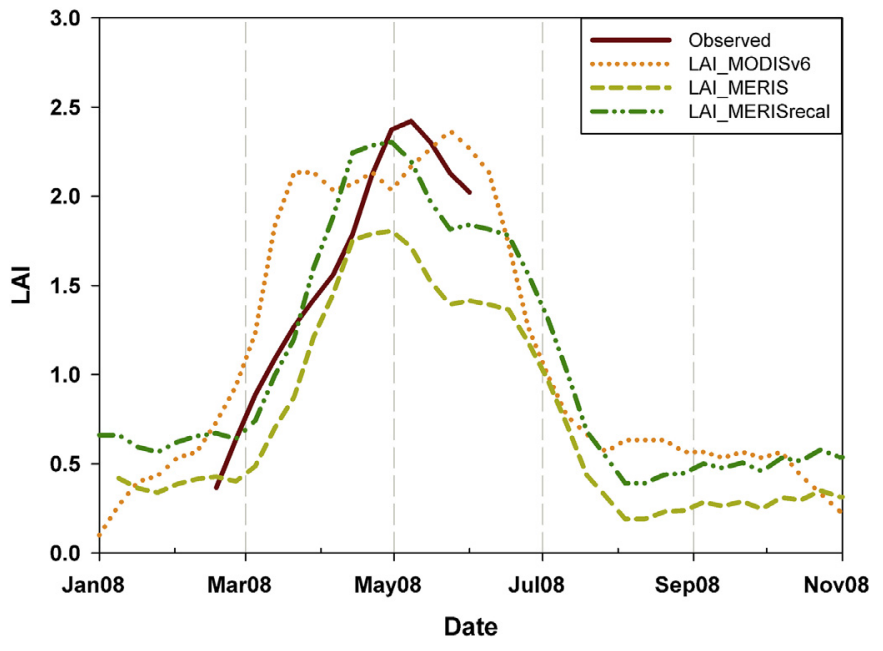

Fig. 3. Annual evolution of LAI values for 2008 
values as experimental data. However, MERIS LAI data were greatly underestimated, such that MERIS values were thus recalibrated using in-situ LAI measurements before incorporating them into SCOPE as input. These new values are also shown in Fig. 3 as LAI_MERISrecal.

\subsection{Photosynthetic parameters}

Photosynthetic parameters might be considered key input parameters in SCOPE since they control carbon fixation/assimilation and are also characteristic for each crop type studied. Initial values for $\mathrm{V}_{\mathrm{cmax}}$ and $\mathrm{J}_{\max }$ were extracted from the literature (Harley et al., 1985; Wullschleger, 1993) and used to run the SCOPE model. When a fixed value for $V_{\text {cmax }}$ and $J_{\max }$ was used for the whole studied period in SCOPE, results (sensitivity analysis not shown in the graphs) revealed differences between observed and modelled data, which lead to seasonality in the value of the photosynthetic parameters being taken into consideration. Values for $\mathrm{V}_{\mathrm{cmax}}$ and $\mathrm{J}_{\max }$ within the range $[20,50] \mu \mathrm{mol} \mathrm{m} \mathrm{m}^{-2}$ $\mathrm{s}^{-1}$ were used as minimum values for the photosynthetic parameters in this paper. These values were applied to the period covering the early stages of crop development (emergence) and the fallow period. Values within the range $[100,190] \mu \mathrm{mol} \mathrm{m} \mathrm{m}^{-2} \mathrm{~s}^{-1}$ were selected as indicative initial maximum values. From the selected initial values (minimum and maximum) used as input for SCOPE, the model itself interpolated $\mathrm{V}_{\mathrm{cmax}}$ and $\mathrm{J}_{\max }$ for the intermediate instantaneous values in order to obtain full seasonality for these photosynthetic parameters. Optimized maximum values were obtained by minimizing the bias and RMSE between modelled and observed data-series for NEE and GPP. We found that for rapeseed these values were 145 and 270 , for $V_{c \max }$ and $\mathrm{J}_{\max }$, respectively.

The new $V_{\text {cmax }}$ and $J_{\max }$ parameters chosen for the crop were selected not only taking into account the minimization of statistical variables/parameters (RMSE, $\mathrm{R}^{2}, \ldots$ ) as commented on, but also the constant ratio between $\mathrm{V}_{\mathrm{cmax}}$ and $\mathrm{J}_{\max }$ referred to in previous studies (Wullschleger, 1993; Van Goethem et al., 2014; Medlyn et al., 2002; Misson et al., 2006; Borjigidai et al., 2006).

\subsection{Carbon balance/ $\mathrm{CO}_{2}$}

Fig. 4 shows the yearly pattern of $8 d$ cumulated NEE and GPP from the beginning of the year to October 2008. This period spanned almost the whole rapeseed development (there are no data for OctoberDecember 2007) since the next crop (wheat) was sown in November 2008. With LAI data from remote sensing, and meteorological data from a nearby station (Pérez et al., 2016), SCOPE was also able to model the fluxes for the period January-March 2008. Therefore, although experimental measurements started in March 2008, modelled values shown in Fig. 4 and later in Fig. 5 commenced in January 2008.

Results show that SCOPE was able to reproduce a similar seasonal trend to that measured for the carbon fluxes. Specifically, SCOPE accurately reproduced sink $(\mathrm{NEE}<0)$ or source $(\mathrm{NEE}>0)$ behaviour along the different growth stages as depicted in Fig. 4. Results for the comparison between observed values and those calculated by SCOPE are displayed in Table 3. Statistical parameters of the linear regression together with bias and RMSE are shown.

The best agreement appeared for the GPP comparison with $\mathrm{R}^{2}$ coefficients that were similar or slightly higher than NEE ones and lower bias, particularly for MERIS data. Slopes always gave values close to 1 with the exception of the NEE MODIS-case, which had a value of around 0.87 .

The total amount of carbon sequestered and assimilated was also calculated for observed values and those modelled with SCOPE. The calculation of the accumulated fluxes revealed the importance of respiratory processes in this kind of agricultural ecosystem. Although the amount of carbon used in photosynthetic processes (total amount of GPP) was high, the total final amount of carbon sequestered by the ecosystem (NEE) only reached $35 \%$ of the total amount of GPP. The
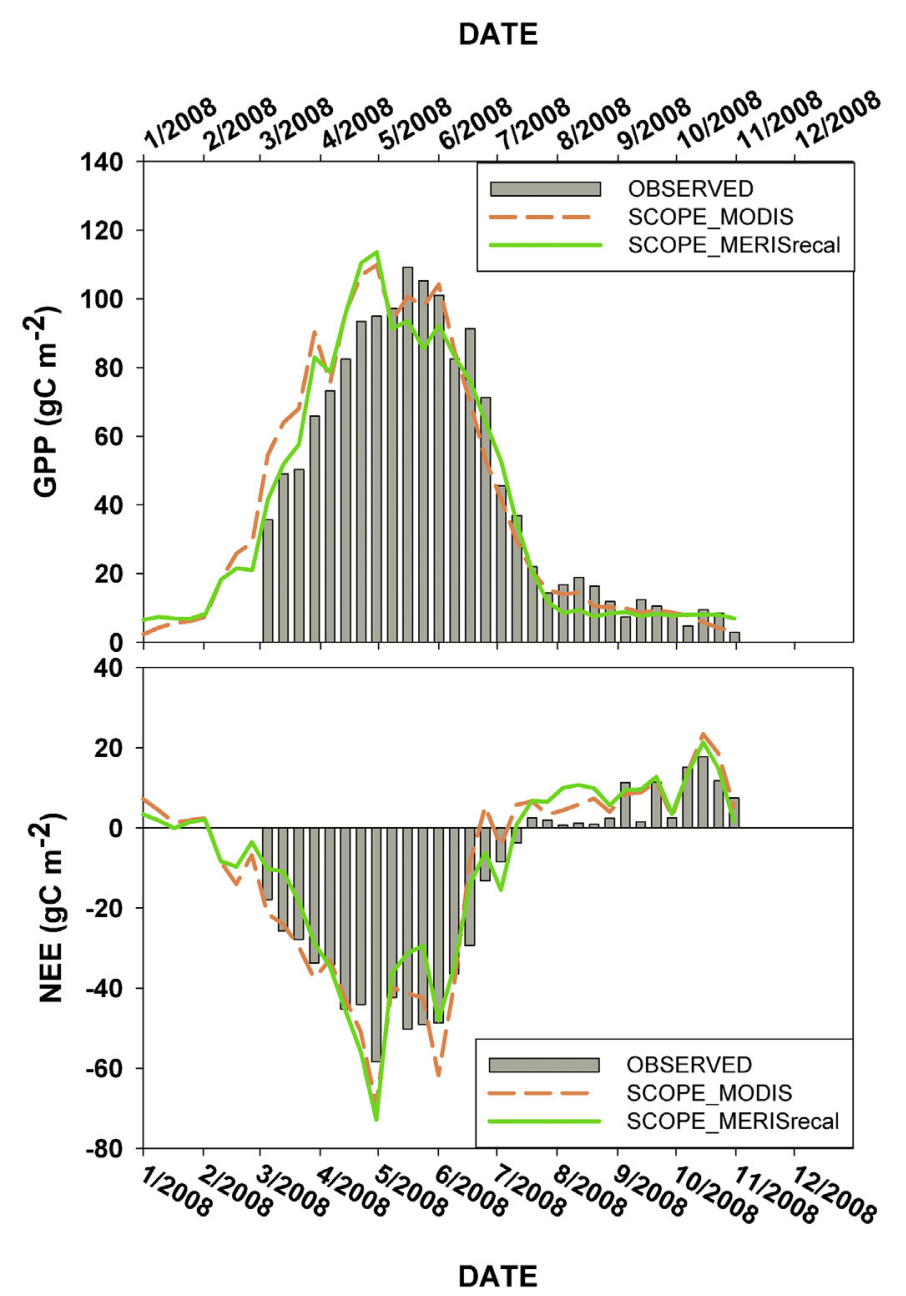

Fig. 4. Seasonal pattern of the 8d NEE and GPP observed and simulated with SCOPE. This graph depicts the temporal series for observed data (OBSERVED GPP/NEE) as well as those calculated by SCOPE using LAI-MODIS (SCOPE_MODIS) and LAI-MERIS (SCOPE_MERISrecal) data.

remaining amount was returned to the atmosphere by respiratory processes. Even so, the behaviour of the crop studied in this paper emerged as a net carbon sink as evidenced by negative NEE values. For a period covering March 2008 to October 2008, the total amount of carbon removed from the atmosphere (NEE) reached values of $-480,-411$ and $-356 \mathrm{gC} \mathrm{m}^{-2}$ for the observed, modelled-MODIS and modelledMERIS data, respectively. Similarly, GPP values reached 1450, 1484 and $1436 \mathrm{gC} \mathrm{m}^{-2}$.

\subsection{Energy fluxes}

The main parameters involved in calculating the energy fluxes are the resistances, as stated in the equations in Section 3.2. The values for the aerodynamic resistances used by SCOPE were fixed depending on the study period (see Section 3.2). Two sets of values were considered depending on meteorological conditions and growth stage. In this study, $r_{s}^{s}$ emerged as one of the main parameters controlling energy fluxes, particularly LE.

Energy fluxes were thus modelled with SCOPE by applying Eqs. (14)-(16). Similar to carbon modelled fluxes, SCOPE values for LE, $\mathrm{H}$ and $\mathrm{G}$ were calculated from January 2008 (see Section 4.3) and are displayed in Fig. 5. This figure reveals the similar pattern followed by observed LE and $G$ values, and those obtained by applying SCOPE. However, for the $\mathrm{H}$-case the model underestimated the values, particularly 
a

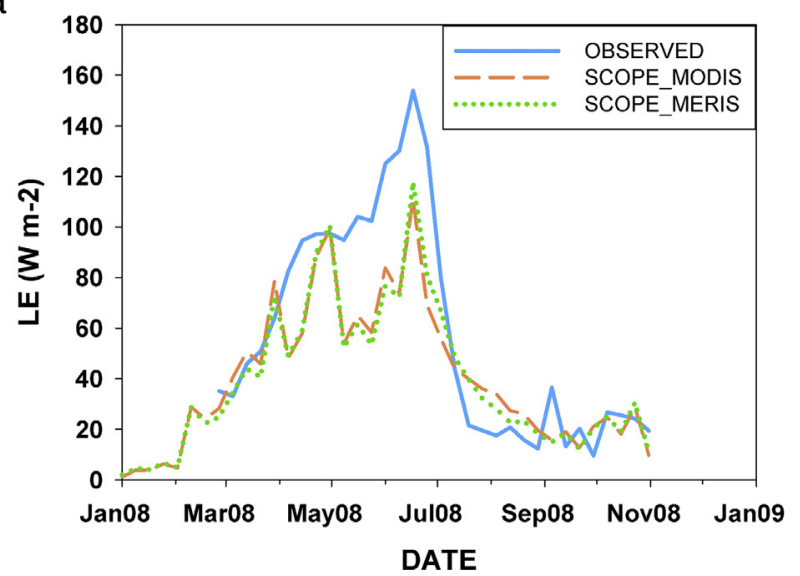

b

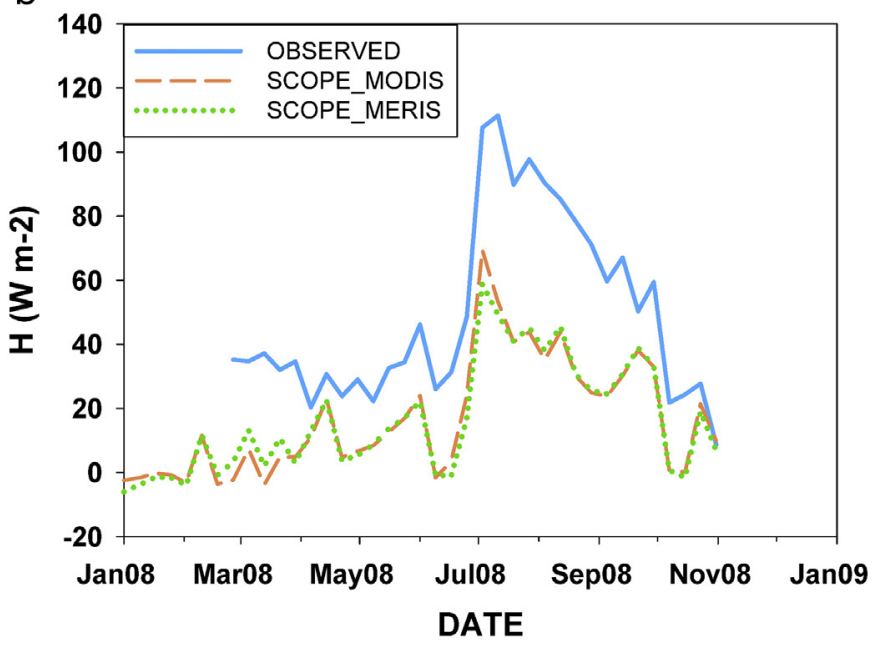

C

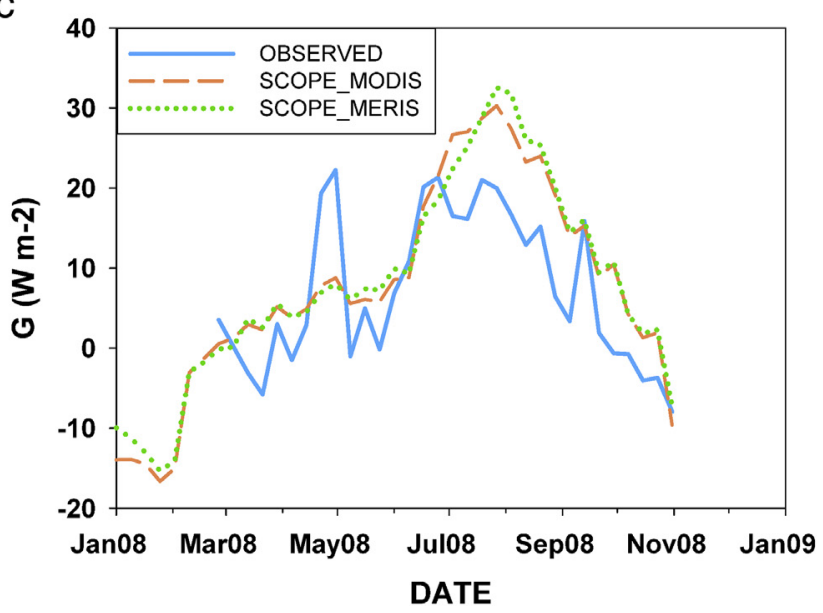

Fig. 5. a-c. Monthly average values for LE, H and G for the whole period studied.

after harvest (July to September). Statistical and comparison results for all these fluxes are shown in Table 3.

\section{Discussion}

\subsection{Accuracy of the input parameters}

The various climate or crop models can be used as tools to evaluate the impact of climate change and elevated atmospheric $\mathrm{CO}_{2}$ on ecosystems (Rosenzweig et al., 2014). Accurately selecting the input parameters for these models remains one of the most important steps in the study. Parameter selection has a major influence on the modelled values, since incorrect parameter selection might cause the model to fail, as stated by Morillas et al. (2013). Yuan et al. (2012) also reported the importance of accurate values for the parameters governing the modelled ecosystem behaviour such as activation energies, the canopy extinction coefficient or the maximum carboxylation rate, which can lead to erroneous simulation of NEE and respiration. Several parameters, used as input in SCOPE, such as $\mathrm{k}_{\mathrm{c}}, \mathrm{k}_{\mathrm{o}}, \Gamma^{*}, \mathrm{C}_{\mathrm{ab}}, \mathrm{C}_{\mathrm{s}}, \mathrm{C}_{\mathrm{w}}, \mathrm{C}_{\mathrm{dm}}$ and $\mathrm{N}$ can be assumed invariant across species as stated in Kim and Lieth (2003). However, other parameters are specific for each vegetation type.

There is agreement in the literature concerning the existence of key parameters when Farquhar's photosynthesis model is applied (Harley et al., 1986). These parameters are: photosynthetic parameters $V_{\text {cmax }}$ and $\mathrm{J}_{\max }$ when the leaf level is considered (Fan et al., 2011; Kattge and Knorr, 2007; Misson et al., 2006), and LAI when the photosynthesis rate is upscaled to the whole canopy (Ju et al., 2010).

Correction of LAI values from remote sensing is a widely employed approach when these values are used as input in crop modeling. Tang et al. (2011) used this approach for LAI-MODIS retrievals in wheat and corn cultivars. Their results showed similar results to those found in this paper, with a clear underestimation of MODIS data when compared to observed LAI.

Since LAI is one of the main parameters involved in carbon calculation, the pattern of this parameter determines the pattern of fluxes. Maximum values for these fluxes should therefore be determined by the maximum values for LAI. An accurate temporal data-series of LAI could thus lead to a more accurate representation of these fluxes calculated by SCOPE. In this study, MODIS and MERIS were used as remote sensing sources of input data for the model. However, given the wide availability of sensors that measure similar data, others such as Landsat (Tang et al., 2013) could be used.

\subsection{Photosynthesis key parameters}

There is abundant literature regarding biophysical parameters. Most studies refer to forest or other vegetation types although fewer address crops similar to the one evaluated in the present analysis. The relationship or dependence of photosynthesis on the photosynthetic parameters $\mathrm{V}_{\mathrm{cmax}}$ and $\mathrm{J}_{\max }$ has been widely analysed in previous studies (Walker et al., 2014). The difference in $\mathrm{CO}_{2}$ assimilation capacity between species was demonstrated in the study carried out by Wullschleger (1993), and also described in other studies such as Wilson et al. (2001). Moreover, in the latter, not only was the difference between species proved but it was also shown that a difference exists even for the same species. Therefore, as reported in previous studies, values for $\mathrm{V}_{\mathrm{cmax}}$ and $\mathrm{J}_{\max }$ might vary by up to $30 \%$ or more (Xu and Baldocchi, 2003) even when evaluating the same genus or plant.

In this study, we obtained maximum values of 145 and 270 $\mu \mathrm{mol} \mathrm{m} \mathrm{m}^{-2} \mathrm{~s}^{-1}$ for $\mathrm{V}_{\mathrm{cmax}}$ and $\mathrm{J}_{\max }$, respectively, for rapeseed. Lower values for these parameters were obtained by Lu et al. (2016) in a controlled experiment over a $20 \mathrm{~m}^{2}$ rapeseed field in China using two different K-treatments. They showed values in a range of [70.9, $120.5] \mu \mathrm{mol} \mathrm{m} \mathrm{m}^{-2} \mathrm{~s}^{-1}$ for $\mathrm{V}_{\mathrm{cmax}}$ and $[114.5,170.6] \mu \mathrm{mol} \mathrm{m}^{-2} \mathrm{~s}^{-1}$ for $J_{\max }$. Monti et al. (2009) studied isolated mustard plants (similar to rapeseed) under different light exposure conditions and obtained $\mathrm{V}_{\mathrm{cmax}}$ values from 65 to $113 \mu \mathrm{mol} \mathrm{m}^{-2} \mathrm{~s}^{-1}$, and $\mathrm{J}_{\max }$ from 108 to $222 \mu \mathrm{mol} \mathrm{m}{ }^{-2} \mathrm{~s}^{-1}$.

The range for $\mathrm{V}_{\mathrm{cmax}}$ and $\mathrm{J}_{\max }$ values is fairly dependent on canopy development or type, as stated in the literature. These parameters have been widely studied for different species and locations (Monson and Baldocchi, 2014). Dependence of photosynthetic parameters on temperature has also been widely studied and proven in the literature. Therefore, as temperature increases, $\mathrm{V}_{\mathrm{cmax}}$ and $\mathrm{J}_{\max }$ values will also increase with an impact on photosynthesis and carbon assimilation, as stated in Harley et al. (1985) for soybean with values within the range $[59,260] \mu \mathrm{mol} \mathrm{m} \mathrm{m}^{-2} \mathrm{~s}^{-1}$ covering temperatures from 20 to $40^{\circ} \mathrm{C}$. 
Table 3

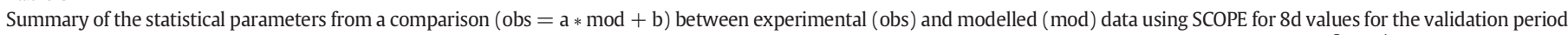

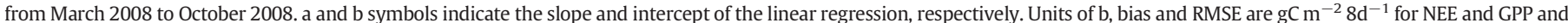
$\mathrm{W} \mathrm{m}^{-2}$ for $\mathrm{LE}, \mathrm{H}$ and $\mathrm{G}$.

\begin{tabular}{|c|c|c|c|c|c|c|c|c|c|c|}
\hline & \multicolumn{5}{|c|}{ MODIS } & \multicolumn{5}{|c|}{ MERIS } \\
\hline & Slope & Interc. & $\mathrm{R}^{2}$ & Bias & RMSE & Slope & Interc. & $\mathrm{R}^{2}$ & Bias & RMSE \\
\hline NEE & 0.87 & -3.93 & 0.93 & 2.22 & 7.25 & 0.91 & -4.99 & 0.90 & 4.01 & 8.65 \\
\hline GPP & 0.91 & 3.02 & 0.93 & 1.07 & 10.21 & 0.94 & 3.13 & 0.94 & -0.47 & 9.22 \\
\hline LE & 1.43 & -8.51 & 0.77 & -11.39 & 25.77 & 1.39 & -5.63 & 0.80 & -12.16 & 25.04 \\
\hline $\mathrm{H}$ & 1.38 & 21.27 & 0.78 & -28.98 & 32.58 & 1.51 & 18.85 & 0.81 & -29.07 & 32.64 \\
\hline G & 0.73 & -1.03 & 0.63 & 4.09 & 7.45 & 0.69 & -0.80 & 0.57 & 4.38 & 8.08 \\
\hline
\end{tabular}

Although the seasonality of these photosynthetic parameters has been widely proven (Misson et al., 2006; Xu and Baldocchi, 2003), $\mathrm{V}_{\mathrm{cmax}}$ and $\mathrm{J}_{\max }$ values might be assumed constant since seasonality is incorporated by upscaling photosynthesis rates using LAI. Applying the methodology followed in the literature (Groenendijk et al., 2011b), setting a fixed value for the $V_{c \max }$ and $J_{\max }$ parameters is thus an approach that might lead to acceptable modelled values for NEE and GPP. In this kind of approach, the mean value for the whole growing season or, the maximum crop-specific value, is used as the said fixed value. However, this approach might induce a major deviation in carbon flux values (Wilson et al., 2001; Zhou et al., 2014), a fact also confirmed by a sensitivity analysis performed in this paper (not shown). Therefore, indicating a range of values to introduce the seasonal variation of $\mathrm{V}_{\mathrm{cmax}}$ and $\mathrm{J}_{\max }$, as done in this paper, would be desirable. These values were calibrated by minimizing the bias between observed and modelled $\mathrm{CO}_{2}$ fluxes (NEE and GPP), as stated in Section 4.2. Once calibrated, these parameters could be considered characteristic values for $\mathrm{CO}_{2}$ assimilation for rapeseed.

LAI is one of the main variables used in fluxes and photosynthesis calculation (Li et al., 2011). Therefore, in SCOPE this variable might carry greater weight in the calculation than $\mathrm{V}_{\mathrm{cmax}}$ or $\mathrm{J}_{\max }$ since it also reports the seasonality of plant growth. However, the results shown in Sections 4.1 and 4.2 revealed that all three parameters should be considered equally important when using the model and none of them should be ignored in the calculations, since the best results for the modelled carbon fluxes were obtained when seasonality was included in SCOPE, whether using either LAI or photosynthetic parameters. This statement is also in agreement with the conclusions obtained by Zhang et al. (2014) who evaluated SCOPE when calculating sun-induced chlorophyll fluorescence and GPP.

\subsection{Carbon fluxes}

Results showed that SCOPE reproduces seasonal trend and maximum/minimum values for NEE and GPP fairly accurately. Results revealed that SCOPE is able to reproduce seasonality in carbon fluxes (Fig. 4) as does another crop-specific model (Wu et al., 2016).

The cumulative observed value for NEE for the period covering March 2008 to October 2008 was $-480 \mathrm{gC} \mathrm{m}^{-2}$ for rapeseed. The cumulative modelled values for NEE were, regardless of whether the sensor used for LAI data was either MODIS or MERIS, quite similar to those reported in Section 4.3, although they were somewhat underestimated when using MERIS data. This underestimation might be due to respiration modeling, but also to the fact that maximum LAI values during MIP for the MERIS dataset, even when recalibrated, were lower than expected (see Fig. 3), decreasing in value before the MODIS ones from mid-May to mid-June. Revill et al. (2013) and Sus et al. (2010) reported similar total values for NEE of wheat observed and simulated with a SPA model in Europe. It should be pointed out, however, that they did not include the fallow period when the ecosystem usually behaves as a source leading to a lower total amount of NEE. At the same location as Revill et al. (2013) and Sus et al. (2010), South West France, Béziat et al. (2009) obtained a total net ecosystem production of $-286 \mathrm{gC} \mathrm{m}^{-2}$ for rapeseed from March 2005 to March 2006, a period which also covered part of the growth of the wheat seeded after the rapeseed cycle.

Across the whole study period, the results shown in Section 4.3 reveal a significant positive relationship between experimental GPP and modelled assimilation as well as for NEE. The differences between NEE and GPP cumulative values given in Section 4.3 imply high rates of respiration by the studied agricultural ecosystem. Moreover, the studied crop behaves as a net carbon sink. As regards these results, SCOPE is still able to replicate not only the seasonal pattern of NEE and assimilation/GPP but also the total amount of $\mathrm{CO}_{2}$ /carbon sequestered by the crop, although the total annual amount obtained with SCOPE tended to be slightly underestimated, probably due to the inaccuracy of LAI data from remote sensing or to respiration modeling. Furthermore, a slight difference might be found between results from SCOPE when using either MODIS or MERIS. Coops et al. (2007) applied a physiological model (3PGS) to simulate GPP over a forest in Vancouver Island. Instead of LAI, as used in this paper, they used fPAR as input for the model and obtained similar results to those obtained for our studied ecosystem, when comparing observed and modelled data. The difference in results depending on the source used for retrieving the vegetation indices included in the model was also reported by Coops et al. (2007), reflecting the importance of accurate LAI or fPAR data as commented earlier in Section 5.1.

\subsection{Energy fluxes}

Due to the influence of aerodynamic resistances, the study period was partitioned into a dry and a wet period. For each of these periods, different values for the aerodynamic resistances were considered as mentioned in previous sections. North et al. (2015) also evaluate a 1D two-source SVAT model called SimSphere to simulate LE and H, considering stomatal resistance as an important factor in calculations.

Results obtained by modeling energy fluxes with SCOPE revealed better agreement for $\mathrm{LE}$ and $\mathrm{G}$ than for $\mathrm{H}$, regarding the seasonal pattern displayed in Fig. 5. However, the statistical results are acceptable for all three variables, as shown in Table 3. A similar range for bias and for RMSE was obtained for LE and $\mathrm{H}$ with values within the range $(-30$, $-13)$ for bias and $(25,33)$ for RMSE. Lower values were reached for the $\mathrm{G}$ case.

Xu et al. (2014) compared simulated energy fluxes by using both two-source and one-source models, reporting better results using the dual-source over the one-source model. Their results for two croplands are in agreement with the results shown for our study site, also a cropland, although the RMSE values for LE and $\mathrm{H}$ obtained in this paper are lower than those reported by Xu et al. (2014). Moreover, in contrast to their reported results, SCOPE tended to model LE better than $\mathrm{H}$.

\section{Conclusion}

In this paper we sought to apply the SCOPE model to agricultural land in order to assess the model's reliability for predicting the behaviour of a selected ecosystem as a carbon sink or source, for which purpose a rapeseed cropland was studied. 
The SCOPE model was able to simulate NEE, assimilation/GPP and energy fluxes. Ancillary variables required to run SCOPE were measured at the experimental site. These variables included air and soil temperature, radiation, wind speed, LAI, and soil moisture.

Due to the marked seasonal pattern of the various fluxes characterizing crop development or the lack of vegetation, calibrating the model in order to obtain modelled values which can reliably reproduce those fluxes was one of the main tasks of this work. Moreover, obtaining characteristic vegetation parameters, $\mathrm{V}_{\mathrm{cmax}}$ and $\mathrm{J}_{\max }$, related to the studied crop might help to expand the bibliography on this crop, for which information is lacking at times.

As proven in this paper, two sets of values mainly influence simulations and results in SCOPE: first, biophysical parameters which characterize the various crop features, the influence of such parameters relying on biochemical processes, and therefore impacting on NEE, GPP, and respiration; second, aerodynamic resistances calculated inside the algorithm which are dependent on initial values fixed for those resistances, particularly, $\mathrm{r}_{\mathrm{s}}^{\mathrm{s}}$. Unlike biophysical parameters, aerodynamic resistances impact more markedly on energy flux calculation than on other variables.

The biochemical model used by SCOPE takes $\mathrm{CO}_{2}$ concentration into consideration when simulating photosynthesis. This feature of the model makes it useful for evaluating the response of/changes in plant photosynthesis regarding a continuously increasing $\mathrm{CO}_{2}$ concentration as shown in several reports related to climate change (IPCC, 2013).

\section{Acknowledgments}

The authors would like to thank the financial support provided jointly by ERDF (The European Regional Development Fund) and MICINN (in the framework of projects CGL2009-11979 and CGL2014-53948-P) for carrying out this research. The authors also wish to thank NASA for providing us with free access to MODIS images, and the ESA, for providing us with MERIS data in the framework of a CAT1 project.

Finally, the authors would also like to express their gratitude to Carlos Blanco for his contribution to data processing, and Jerónimo Alonso, owner of the Monte de Rocío farm where measurements were performed.

\section{References}

Atzberger, C., Richter, K., 2012. Spatially constrained inversion of radiative transfer models for improved LAI mapping from future Sentinel-2 imagery. Remote Sens. Environ. 120, 208-218.

Bernacchi, C.J., Singsaas, E.L., Pimentel, C., Portis Jr., A.R., Long, S.P., 2001. Improved temperature response functions for models of rubisco-limited photosynthesis. Plant Cell Environ. 24 (2), 253-259.

Béziat, P., Ceschia, E., Dedieu, G., 2009. Carbon balance of a three crop succession over two cropland sites in South West France. Agric. For. Meteorol. 149 (10), 1628-1645

Borjigidai, A., Hikosaka, K., Hirose, T., Hasegawa, T., Okada, M., Kobayashi, K., 2006. Seasonal changes in temperature dependence of photosynthetic rate in rice under free-air $\mathrm{CO}_{2}$ enrichment. Ann. Bot. 97 (4), 549-557.

Burba, G., Anderson, D., 2010. A Brief Practical Guide to Eddy Covariance Flux Measurements: Principles and Workflow Examples for Scientific and Industrial Applications. LI-COR, Inc. https://doi.org/10.13140/RG.2.1.1626.4161.

Chen, J.M., Liu, J., Cihlar, J., Goulden, M.L., 1999. Daily canopy photosynthesis mode through temporal and spatial scaling for remote sensing applications. Ecol. Model. $124(2-3), 9-119$.

Choudhury, B.J., Idso, S.B., Reginato, R.J., 1987. Analysis of an empirical model for soil heat flux under a growing wheat crop for estimating evaporation by an infraredtemperature based energy balance equation. Agric. For. Meteorol. 39 (4), 283-297.

Clough, S.A., Shephard, M.W., Mlawer, E.J., Delamere, J.S., Iacono, M.J., Cady-Pereira, K., Boukabara, S., Brown, P.D., 2005. Atmospheric radiative transfer modeling: a summary of the AER codes. J. Quant. Spectrosc. Radiat. Transf. 91, 233-244.

Coops, N.C., Black, T.A., Jassal, R.S., Trofymow, J.A., Morgenstern, K., 2007. Comparison of MODIS, eddy covariance determined and physiologically modelled gross primary production (GPP) in a Douglas-fir forest stand. Remote Sens. Environ. 107 (3), 385-401.

Dai, Y., Dickinson, R.E., Wang, Y.-P., 2004. A two-big-leaf model for canopy temperature, photosynthesis, and stomatal conductance. J. Clim. 17 (12), 2281-2299.

Dorigo, W.A., Zurita-Milla, R., de Wit, A.J.W., Brazile, J., Singh, R., Schaepman, M.E., 2007. A review on reflective remote sensing and data assimilation techniques for enhanced agroecosystem modeling. Int. J. Appl. Earth Obs. Geoinf. 9 (2), 165-193.
Du, S., Liu, L., Liu, X., Hu, J., 2017. Response of canopy solar-induced chlorophyll fluorescence to the absorbed photosynthetically active radiation absorbed by chlorophyll. Remote Sens. 9 (911). https://doi.org/10.3390/rs9090911.

Falge, E., Baldocchi, D., Olson, R., Anthoni, P., Aubinet, M., Bernhofer, C., Burba, G., Ceulemans, R., Clement, R., Dolman, H., Granier, A., Gross, P., Grünwald, T., Hollinger, D., Jensen, N.-O., Katul, G., Keronen, P., Kowalski, A., Lai, C.T., Law, B.E., Meyers, T., Moncrieff, J., Moors, E., Munger, J.W., Pilegaard, K., Rannik, Ü., Rebmann, C., Suyker, A., Tenhunen, J., Tu, K., Verma, S., Vesala, T., Wilson, K., Wofsy, S., 2001. Gap filling strategies for defensible annual sums of net ecosystem exchange. Agric. For. Meteorol. 107 (1), 43-69.

Fan, Y., Zhong, Z., Zhang, X., 2011. Determination of photosynthetic parameters $\mathrm{V}_{\mathrm{cmax}}$ and $I_{\max }$ for a $\mathrm{C}_{3}$ plant (spring hulless barley) at two altitudes on the Tibetan Plateau. Agric. For. Meteorol. 151 (12), 1481-1487.

Farquhar, G.D., von Caemmerer, S., Berry, J.A., 1980. A biochemical model of photosynthetic $\mathrm{CO}_{2}$ assimilation in leaves of $\mathrm{C} 3$ species. Planta 149 (1), 78-90.

Frield, M.A., 2002. Forward and inverse modeling of land surface energy balance using surface temperature measurements. Remote Sens. Environ. 79, 344-354

Gonzalez-Dugo, M.P., Neale, C.M.U., Mateos, L., Kustas, W.P., Prueger, J.H., Anderson, M.C., Li, F., 2009. A comparison of operational remote sensing-based models for estimating crop evapotranspiration. Agric. For. Meteorol. 149 (11), 1843-1853.

González-Sanpedro, M.C., Le Toan, T., Moreno, J., Kergoat, L., Rubio, E., 2008. Seasonal variations of leaf area index of agricultural fields retrieved from Landsat data. Remote Sens. Environ. 112 (3), 810-824.

Groenendijk, M., Dolman, A.J., Ammann, C., Arneth, A., Cescatti, A., Dragoni, D., Gash, J.H.C., Gianelle, D., Gioli, B., Kiely, G., Knohl, A., Law, B.E., Lund, M., Marcolla, B., van der Molen, M.K., Montagnani, L, Moors, E, Richardson, A.D, Roupsard, O, Verbeeck, H, Wohlfahrt, G., 2011a. Seasonal variation of photosynthetic model parameters and leaf area index from global Fluxnet eddy covariance data. J. Geophys. Res. 116 (G04027), 1-18.

Groenendijk, M., Dolman, A.J., van der Molen, M.K., Leuning, R., Arneth, A., Delpierre, N., Gash, J.H.C., Lindroth, A., Richardson, A.D., Verbeeck, H., Wohlfahrt, G., 2011b. Assessing parameter variability in a photosynthesis model within and between plant functional types using global Fluxnet eddy covariance data. Agric. For. Meteorol. 151 (1), 22-38.

Harley, P.C., Tenhunen, J.D., Lange, O.L., 1986. Use of an analytical model to study limitations on net photosynthesis in Arbutus unedo field conditions. Oecologia 70, 393-401.

Harley, P.C. Weber, J.A., Gates, D.M., 1985. Interactive effects of light, leaf temperature, $\mathrm{CO}_{2}$ and $\mathrm{O}_{2}$ on photosynthesis in soybean. Planta 165 (2), 249-263.

IPCC, 2013. Climate Change 2013: The Physical Sciences Basis. Contribution of Working Group I to the Fifth Assessment Report of the Intergovernmental Panel on Climate Change. Cambridge University Press, UK, p. 1535.

Jacquemoud, S., Baret, F., 1990. PROSPECT: a model of leaf optical properties spectra. Remote Sens. Environ. 34 (2), 75-91.

Jacquemoud, S. Verhoef, W., Baret, F., Bacour, C. Zarco-Tejada, P.J., Asner, G.P., François, C., Ustin, S.L., 2009. PROSPECT + SAIL models: a review of use for vegetation characterization. Remote Sens. Environ. 113 (Suppl. 1), S56-S66.

Ju, W., Wang, S., Yu, G., Zhou, Y., Wang, H., 2010. Modeling the impact of drought on canopy carbon and water fluxes for a subtropical evergreen coniferous plantation in southern China through parameter optimization using an ensemble Kalman filter. Biogeosciences 7 (3), 845-857.

Kalma, J.D., McVicar, T.R., McCabe, M.F., 2008. Estimating land surface evaporation: a review of methods using remotely sensed surface temperature data. Surv. Geophys. 29 (4-5), 421-469.

Kattge, J., Knorr, W., 2007. Temperature acclimation in a biochemical model of photosynthesis: a reanalysis of data from 36 species. Plant Cell Environ. 30 (9), 1176-1190.

Kim, S., Lieth, J.H., 2003. A coupled model of photosynthesis, stomatal conductance and transpiration for a Rose leaf (Rosa hybrid L.). Ann. Bot. 91 (7), 771-781.

Kötz, B., Schaepman, M., Morsdorf, F., Bowyer, P., Itten, K., Allgöwer, B., 2004. Radiative transfer modeling within a heterogeneous canopy for estimation of forest fire fuel properties. Remote Sens. Environ. 92 (3), 332-344.

Kremer, C., Stöckle, C.O., Kemanian, A.R., Howell, T., 2008. A canopy transpiration and photosynthesis model for evaluating simple crop productivity models. Chapter 6 . In: Ahuja, L.R., Reddy, V.R., Saseendran, S.A., Yu, Qiang (Eds.), Response of Crops to Limited Water: Understanding and Modeling Water Stress Effects on Plant Growth Processes. 2008, pp. 165-189.

Kustas, W.P., Humes, K.S., Norman, J.M., Moran, M.S., 1996. Single- and dual-source modeling of surface energy fluxes with radiometric surface temperature. J. Appl. Meteorol. 35 (1), 110-121

Leclerc, M.Y., Foken, T., 2014. Footprints in Micrometeorology and Ecology. SpringerVerlag, Berlin ISBN 978-3-642-54544-3. (275 pp.).

Lenz, K.E., Host, G.E., Roskoski, K., Noormets, A., Sôber, A., Karnosky, D.F., 2010. Analysis of a Farquhar-von Caemmerer-Berry leaf-level photosynthetic rate model for Populus tremuloides in the context of modeling and measurement limitations. Environ. Pollut. 158 (4), 1015-1022.

Li, Z.-L., Tang, R., Wan, Z., Bi, Y., Zhou, C., Tang, B., Yan, G., Zhang, X., 2009. A review of current methodologies for regional evapotranspiration estimation from remotely sensed data. Sensors 9 (5), 3801-3853.

Li, L., Vuichard, N., Viovy, N., Ciais, P., Wang, T., Ceschia, E., Jans, W., Wattenbach, M., Béziat, P., Gruenwald, T., Lehuger, S., Bernhofer, C., 2011. Importance of crop varieties and management practices: evaluation of a process-based model for simulating $\mathrm{CO}_{2}$ and $\mathrm{H}_{2} \mathrm{O}$ fluxes at five European maize (Zea mays L.) sites. Biogeosciences 8 (6), $1721-1736$

Liang, S., Li, X., Wang, J. (Eds.), 2012. Advanced Remote Sensing: Terrestrial Information Extraction and Applications. 799. Academic Press, Oxford. ISBN: 978-0-12-385954-9 ISBN.

Liu, L., Liu, X., Hu, J., Guan, L., 2017. Assessing the wavelength-dependent ability of solarinduced chlorophyll fluorescence to estimate the GPP of winter wheat at the canopy 
level. Int. J. Remote Sens. 38 (15):4396-4417. https://doi.org/10.1080/ 01431161.2017.1320449.

Lu, Z., Ren, T., Pan, Y., Li, X., Cong, R., Lu, J., 2016. Differences on photosynthetic limitations between leaf margins and leaf centers under potassium deficiency for Brassica napus L. Sci. Rep. 6, 21725. https://doi.org/10.1038/srep21725 (Nature Publisher Group).

Mauder, M., Foken, T., 2004. Documentation and Instruction Manual of the Eddy Covariance Software Package TK2. Universität Bayreuth, Abteilung Mikrometeorologie, Arbeitsergebnisse Nr. 26, p.45. (ISSN 1614-8916).

Medlyn, B.E., Dreyer, E., Ellsworth, D., Forstreuter, M., Harley, P.C., Kirschbaum, M.U.F., Le Roux, X., Montpied, P., Strassemeyer, J., Walcroft, A., Wang, K., Loustau, D., 2002. Temperature response of parameters of a biochemically based model of photosynthesis. II. A review of experimental data. Plant Cell Environ. 25 (9), 1167-1179.

Misson, L., Tu, K., Boniello, R.A., Goldstein, A.H., 2006. Seasonally of photosynthetic parameters in a multi-specific and vertically complex forest ecosystem in the Sierra Nevada of California. Tree Physiol. 26 (6), 729-741.

Monson, R., Baldocchi, D., 2014. Chapter 5: Modeling the metabolic $\mathrm{CO}_{2}$ flux. Terrestrial Biosphere-Atmosphere Fluxes. Cambridge University Press, pp. 89-110 ISBN: 9781-107-04065-6.

Monti, A., Bezzi, G., Venturi, G., 2009. Internal conductance under different light conditions along the plant profile of Ethiopian mustard (Brassica carinata A. Brown.). J. Exp. Bot. 60 (8), 2341-2350.

Morillas, L., García, M., Nieto, H., Villagarcía, L., Sandholt, I., Gonzalez-Dugo, M.P., ZarcoTejada, P.J., Domingo, F., 2013. Using radiometric surface temperature for surface energy flux estimation in Mediterranean drylands from a two-source perspective. Remote Sens. Environ. 136, 234-246.

Norman, J.M., Kustas, W.P., Humes, K.S., 1995. Source approach for estimating soil and vegetation energy fluxes in observations of directional radiometric surface temperature. Agric. For. Meteorol. 77 (3-4), 263-293.

North, M.R., Petropoulos, G.P., Ireland, G. McCalmont, J.P. 2015. Appraising the capability of a land biosphere model as a tool in modelling land surface interactions: results from its validation at selected European ecosystems. Earth Syst. Dynam. Discuss. 6, 217-265.

Pardo, N., Sánchez, M.L., Pérez, I.A., García, M.A., 2015. Energy balance and partitioning over a rotating rapeseed crop. Agric. Water Manag. 161, 31-40.

Pardo, N., Sánchez, M.L., Timmermans, J., Su, Z., Pérez, I.A., García, M.A., 2014. SEBS validation in a Spanish rotating crop. Agric. For. Meteorol. 195-196, 132-142.

Pérez, I.A., Sánchez, M.L., García, M.A., Pardo, N., 2016. Features of the annual evolution of $\mathrm{CO}_{2}$ and $\mathrm{CH}_{4}$ in the atmosphere of a Mediterranean climate site studied using a nonparametric and harmonic function. Atmos. Pollut. Res. 7, 1013-1021.

Revill, A., Sus, O., Barrett, B., Williams, M., 2013. Carbon cycling of European croplands: a framework for the assimilation of optical and microwave Earth observation data. Remote Sens. Environ. 137, 84-93.

Rosenzweig, C. Elliott, J., Deryng D., Ruane, A.C., Müller, C. Arneth, A. Boote, KJ., Folberth, C., Glotter, M., Khabarov, N., Neumann, K., Piontek, F., Pugh, T.A.M., Schmid, E., Stehfest, E., Yang, H., Jones, J.W., 2014. Assessing agricultural risks of climate change in the 21st century in a global gridded crop model intercomparison. Proc. Natl. Acad. Sci. U. S. A. 111 (9), 3268-3273.

Sánchez, M.L., Pardo, N., Pérez, I.A., García, M.A., 2015. GPP and maximum light use efficiency estimates using different approaches over a rotating biodiesel crop. Agric. For. Meteorol. 214-215, 444-455.

Shuttleworth, W.J., Wallace, J.S., 1985. Evaporation from sparse crops - an energy combination theory. Q. J. R. Meteorol. Soc. 111 (469), 839-855.

Sierra, C.A., Harmon, M.E., Thomann, E., Perakis, S.S., Loescher, H.W., 2011. Amplification and dampening of soil respiration by changes in temperature variability. Biogeosciences 8 (4), 951-961.

Song, L., Kustas, W.P., Liu, S., Colaizzi, P.D., Nieto, H., Xu, Z., Ma, Y., Li, M., Xu, T., Agam, N., Tolk, J.A., Evett, S.R., 2016. Applications of a thermal-based two-source energy balance model using Priestley-Taylor approach for surface temperature partitioning under advective conditions. J. Hydrol. 540, 574-587.

Sus, O., Williams, M., Bernhofer, C., Béziat, P., Buchmann, N., Ceschia, E., Doherty, R. Eugster, W., Grünwald, T., Kutsch, W., Smith, P., Wattenbach, M., 2010. A linked carbon cycle and crop developmental model: Description and evaluation against measurements of carbon fluxes and carbon stocks at several European agricultural sites Agric. Ecosyst. Environ. 139 (3), 402-418.

Tang, R., Li, Z.-L., Jia, Y., Li, C., Chen, K.-S., Sun, X., Lou, J., 2013. Evaluating one- and twosource energy balance models in estimating surface evapotranspiration from Landsat-derived surface temperature and field measurements. Int. J. Remote Sens. 34 (9-10), 3299-3313.

Tang, R., Li, Z.-L., Jia, Y., Li, C., Sun, X., Kustas, W.P., Anderson, M.C., 2011. An intercomparison of three remote sensing-based energy balance models using Large Aperture Scintillometer measurements over a wheat-corn production region. Remote Sens. Environ. 115 (12), 3187-3202

Thum, T., Zaehle, S., Köhler, P., Aalto, T., Aurela, M., Guanter, L., Kolari, P., Laurila, T., Lohila, A., Magnani, F., Van Der Tol, C., Markkanen, T., 2017. Modelling sun-induced fluorescence and photosynthesis with a land surface model at local and regional scales in northern Europe. Biogeosciences 14 (7), 1969-1984.

Timmermans, W., Kustas, W.P., Anderson, M.C., French, A.N., 2007. An intercomparison of the surface energy balance algorithm for land (SEBAL) and the two-source energy balance (TSEB) modeling schemes. Remote Sens. Environ. 108, 369-384.

Van der Tol, C., Verhoef, W., Timmermans, J., Verhoef, A., Su, Z., 2009. An integrated model of soil-canopy spectral radiances, photosynthesis, fluorescence, temperature and energy balance. Biogeosciences 6, 3109-3129.

Van Goethem, D., Potters, G., De Smedt, S., Gu, L., Samson, R., 2014. Seasonal, diurnal and vertical variation in photosynthetic parameters in Phyllostachys humilis bamboo plants. Photosynth. Res. 120 (3), 331-346.

Verhoef, W., 1984. Light scattering by leaf layers with application to canopy reflectance modeling: the SAIL model. Remote Sens. Environ. 16 (2), 125-141.

Verhoef, W., Jia, L., Xiao, Q., Su, Z., 2007. Unified optical-thermal four-stream radiative transfer theory for homogeneous vegetation canopies. IEEE Trans. Geosci. Remote Sens. 45 (6), 1808-1822.

Verrelst, J., Rivera, J.P., Van der Tol, C., Magnani, F., Mohammed, G., Moreno, J., 2015 Global sensitivity analysis of the SCOPE model: what drives simulated canopyleaving sun-induced fluorescence? Remote Sens. Environ. 166, 8-21.

Von Caemmerer, S., 2000. Chapter 2: modelling $C_{3}$ photosynthesis. Biochemical Models of Leaf Photosynthesis. CSIRO Publishing, pp. 29-71 (165 pp.).

Walker, A.P., Beckerman, A.P., Gu, L., Kattge, J., Cernusak, L.A., Domingues, T.F., Scales, J.C. Wohlfahrt, G., Wullschleger, S.D., Woodward, F.I., 2014. The relationship of leaf photosynthetic traits - Vcmax and Jmax - to leaf nitrogen, leaf phosphorus, and specific leaf area: a meta-analysis and modeling study. Ecol. Evol. 4 (16), 3218-3235.

Wallace, J.S., Verhoef, A., 2000. Modelling interactions in mixed-plant communities: light, water and carbon dioxide. In: Marshall, Bruce, Roberts, Jeremy A. (Eds.), Leaf Development and Canopy Growth. Sheffield Academic Press, UK (Chapter 8). (ISBN 0849397693).

Wang, Y.-P., Leuning, R., 1998. A two-leaf model for canopy conductance, photosynthesis and partitioning of available energy I: model description and comparison with a multi-layered model. Agric. For. Meteorol. 91 (1-2), 89-111.

Wang, X., Ma, M., Huang, G., Veroustraete, F., Zhang, Z., Song, Y., Tan, J., 2012. Vegetation primary production estimation at maize and alpine meadow over the Heihe River Basin, China. Int. J. Appl. Earth Obs. Geoinf. 17 (1), 94-101.

Wilson, K.B. Baldocchi, D.D., Hanson, P.J., 2001. Leaf age affects the seasonal pattern of photosynthetic capacity and net ecosystem exchange of carbon in a deciduous forest. Plant Cell Environ. 24 (6), 571-583.

Wu, X., Vuichard, N., Ciais, P.., Viovy, N., de Noblet-Ducoudré, N., Wang, X., Magliulo, V. Wattenbach, M. Vitale, L., Di Tommasi, P., Moors, E.J., Jans, W., Elbers, J., Ceschia, E., Tallec, T., Bernhofer, C., Grünwald, T., Moureaux, C., Manise, T., Ligne, A., Cellier, P., Loubet, B., Larmanou, E., Ripoche, D., 2016. ORCHIDEE-CROP (v0), a new processbased agro-land surface model: model description and evaluation over Europe. Geosci. Model Dev. 9, 857-873.

Wullschleger, S.D., 1993. Biochemical limitations to carbon assimilation in C3 plants - a retrospective analysis of the A/Ci curves from 109 species. J. Exp. Bot. 44 (5), 907-920.

Xin, Q., Gong, P., Li, W., 2015. Modeling photosynthesis of discontinuous plant canopies by linking the geometric optical radiative transfer model with biochemical processes. Biogeosciences 12, 3447-3467.

Xin, X., Liu, Q., 2010. The two-layer surface energy balance parameterization scheme (TSEBPS) for estimation of land surface heat fluxes. Hydrol. Earth Syst. Sci. 14 (3), 491-504.

Xu, L., Baldocchi, D.D., 2003. Seasonal trends in photosynthetic parameters and stomatal conductance of blue oak (Quercus douglasii) under prolonged summer drought and high temperature. Tree Physiol. 23 (13), 865-877.

Xu, T., Bateni, S.M., Liang. S., Entekhabi, D., Mao, K., 2014. Estimation of surface turbulen heat fluxes via variational assimilation of sequences of land surface temperatures from geostationary operational environmental satellites. J. Geophys. Res. Atmos. 119 (18), $10,780-10,798$

Yang, F., Zhou, G., Hunt, J.E., Zhang, F., 2011. Biophysical regulation of net ecosystem carbon dioxide exchange over a temperate desert steppe in Inner Mongolia, China. Agric. Ecosyst. Environ. 142 (3-4), 318-328.

Yuan, W., Liang, S., Liu, S., Weng, E., Luo, Y.., Hollinger, D., Zhang, H., 2012. Improving model parameter estimation using coupling relationships between vegetation production and ecosystem respiration. Ecol. Model. 240, 29-40.

Zhang, Y., Guanter, L., Berry, J.A., Joiner, J., van der Tol, C., Huete, A., Gitelson, A., Voigt, M. Köhler, P., 2014. Estimation of vegetation photosynthetic capacity from space-based measurements of chlorophyll fluorescence for terrestrial biosphere models. Glob. Chang. Biol. 20 (12), 3727-3742.

Zhou, Y., Ju, W., Sun, X., Hu, Z., Han, S., Andrew Black, T., Jassal, R.S., Wu, X., 2014. Close relationship between spectral vegetation indices and Vcmax in deciduous and mixed forests. Tellus Ser. B Chem. Phys. Meteorol. 66 (1), 23279. 